\title{
ПРЕЦЕДЕНТНІ ТОПОНІМИ В НЕОФІЦІЙНИХ НАЗВАХ АМЕРИКАНСЬКИХ МІСТ I ШТАТІВ
}

У статті розглянуто особливості мотивації неофіційних назв американських міст і штатів, які мають у своїй структурі прецедентні топоніми. Досліджувані номінації насамперед пов 'язані з історією, культурою, економікою, національним складом населення міст і регіонів. У ролі прецедентних топонімів функціюють назви географічних об'єктів Старого й Нового Світу, що можуть бути як універсальними культурними символами, так і феноменами, актуальними для носіїв англійської мови, передусім американців. Також досліджувані одиниці містять міфоніми (біблійні назви) та специфічні номінаціі, відомі здебільшого представникам конкретної лінгвокультурної спільноти.

Ключові слова: неофіційна назва, онім, прецедентний топонім, мотивація.

Zosimova O. V. Precedent Toponyms in Informal Names of American Cities and States. Nicknames or informal (alternative) names for geographical objects belong to particularly interesting phenomena in the sphere of proper names. The topicality of an in-depth analysis of this group of nicknames is determined by their wide spread in English-speaking countries as well as their important informative function and ethno-cultural value.

The aim of the research is to identify and describe the main motivational types of informal names of American cities and states that contain precedent toponyms. Our task is also to determine what geographical names serve as precedent phenomena and classify them into groups.

Precedent toponyms used in the nicknames under discussion include geographical names relating to the Old and the New Worlds. They can be both universal cultural symbols (e.g. Athens, Paris, Mecca; New York, Las Vegas) and phenomena that are familiar mostly to native English speakers, particularly Americans (e.g. Birmingham; Saratoga, Lexington and Pittsburgh). Among the precedent toponyms of the first group the component 'Athens' predominates: it functions in over ten nicknames in question as a symbol of art, culture and education. The most popular U.S. toponyms used in the informal place names are 'Chicago' and 'Las Vegas'. The nicknames under discussion also contain mythonyms - biblical place names (e.g. Gomorrah, Eden), and lesser-known onyms that are mainly associated with American or British culture. The nicknames for some U.S. cities are based on the names of famous streets, districts and neighbourhoods (e.g. Wall Street, Hollywood).

The main conclusion of the research is that the nicknames in question are mostly connected with the history, culture, economy and nationality of the first settlers or current inhabitants of various cities and regions.

Key words: informal name, nickname, onym, precedent toponym, motivation.

\section{Ветуп}

Топоніми - неофіційні назви - належать до особливо цікавих феноменів у сфері власних назв. Популярність цього різновиду онімів в англомовній традиції, їхній високий ступінь інформативності та етнокультурне значення зумовлюють потребу ретельного дослідження цієї групи пропріальної лексики. Разом із тим слід відзначити, що порівняно, наприклад, з неофіційною антропонімією, відповідні топоніми вивчені значно меншою мірою. Як правило, дослідники обмежуються лише їхньою згадкою чи побіжною характеристикою в межах огляду системи прізвиськ певної мовної спільноти тощо (див., зокрема, праці О. Леоновича (Леонович, 2007: 11), О. Титаренко 
(Титаренко, 1993: 9), Г. Томахіна (Томахин, 1988: 212)). В. Канна аналізує неофіційні назви деяких штатів та міст США в контексті дослідження конотативних топонімів як особливого типу власних імен (Канна, 2009: 12). Отже, потреба в подальшому детальному вивченні англомовних топонімівпрізвиськ та відповідність цієї проблематики напрямкам сучасних лінгвістичних студій зумовлює актуальність теми нашого дослідження.

Мета цієї статті - з'ясувати особливості мотивації неофіційних назв американських міст та штатів, що мають у своєму складі прецедентні топоніми.

\section{Методи та методики дослідження}

Для досягнення поставленої мети були використані такі методи дослідження: аналітично-описовий - для класифікації та характеристики особливостей різних мотиваційних типів неофіційних назв міст і штатів США, що містять прецедентні топоніми; метод словотвірного аналізу - для з'ясування дериваційної специфіки деяких досліджуваних одиниць; процедура кількісного аналізу - для визначення ступеня продуктивності прецедентних топонімів, що входять до складу неофіційних назв американських прізвиськ міст і штатів.

\section{Результати та дискусії}

Прецедентні феномени - це компоненти знань, позначення й зміст яких добре відомі представникам певної етнокультурної спільноти та які $є$ актуальними й використовуються в когнітивному та комунікативному плані (Селіванова, 2006: 492-493). Одним із різновидів прецедентних феноменів $€$ прецедентні імена, зокрема антропоніми, топоніми, астроніми тощо.

Як відомо, основою багатьох офіційних географічних назв США є назви європейських міст, графств тощо, із яких прибували до нової країни перші переселенці, наприклад: New York, New Jersey, New Hampshire, London, Dublin, Worcester, Manchester, Birmingham; New Bern, New Orleans, New Rochelle, Amsterdam та ін. Так само велика кількість неофіційних номінацій американських міст і штатів грунтується на використанні топонімів, що їх можна розподілити за трьома великими групами, а саме:

1. Назви географічних об’єктів Старого Світу.

Серед них насамперед домінують назви європейських держав і міст тощо, зокрема: Switzerland of America (Colorado; West Virginia; Ouray), Italy of America (Arizona), The Holland of America (Louisiana), Little Norway (Poulsbo), New Sweden (Delaware), Scotland, USA (Alma, Michigan), Birmingham of America (Pittsburgh), Manchester of America (Lowell), Michigan's Little Bavaria (Frankenmuth), Athens of America (Philadelphia; Boston), The American Rome (Washington), Little London (Colorado Springs), Paris of America (Cincinnati), Venice of America (Fort Lauderdale), The Venice of New Jersey (Cranford), Naples on the Gulf (Naples), The Riviera of the Midwest (Muskegon), The Gibraltar of America (Vicksburg); New Andalusia (New Mexico), Waterloo (Austin).

За нашими підрахунками, найбільш продуктивним компонентом номінацій цієї підгрупи є прецедентний топонім Athens, який фігурує в неофіційних назвах щонайменше одинадцяти американських міст, а саме: 
Athens of America (Philadelphia; Boston; Бостон також називають Сучасними Афінами - Modern Athens), Athens of the Prairie (Columbus), Athens of the West (Berkeley; Lexington; Madison), The Athens of the South (Nashville), The Athens of the Mountains (Middlesboro), The Athens of Florida (DeLand), Athens of Indiana (Crawfordsville), The German Athens of America (Milwaukee). Високу частотність використання в межах досліджуваних одиниць мають топоніми Switzerland (назва цієї країни входить до складу семи найменувань американських міст та штатів, як-от: Colorado - Switzerland of America, Sugarcreek - The Little Switzerland of Ohio та ін.) та Paris, шо також функціює у складі як мінімум семи топонімів-неофіційних назв, наприклад: Paris of the Plains (Kansas City), Paris of the South (New Orleans), The Paris of the Midwest (Detroit).

Значно меншою мірою в межах першої групи представлені назви географічних об'єктів Азії, як-от: Baghdad by the Bay (San Francisco), The Bagdad on the Hudson, The Bagdad of the Subway (New York), Beirut by the Lake (Chicago), Hong Kong on the Hudson (New York), Little Manila (Daly City), Black Mecca (Atlanta), America's Mecca (New York). Два американських міста - ЛасВегас та Рено (штат Невада) - мають спільне неофіційне найменування, що містить назву столиці Стародавньої Вавилонії: The Neon Babylon.

Назви африканських країн, за нашими спостереженнями, є основою лише двох неофіційних топонімів США, а саме південної частини штату Іллінойс (Little) Egypt та столиці штату Огайо Коламбуса - Somaliwood, що пов'язане з досягненнями представників великої сомалійської діаспори цього міста в кіноіндустрії (друга частина контамінованого слова походить від Hollywood) (Wikipedia, n.d. ${ }^{1}$.

2. Назви географічних об'єктів Нового Світу.

Власне топонім America у функції основного компонента досліджуваних одиниць фігурує в небагатьох номінаціях, зокрема: America in Miniature (Maryland), Native America (Oklahoma). Переважну більшість онімів цієї групи складають назви міст, штатів і регіонів США, наприклад: Little Chicago (Sioux City; North Platte), The Chicago of the South (Decatur), New York of the South (New Orleans), The L.A. of the Mountain West (Denver); Little Las Vegas (Middlesboro), Las Vegas of the Ozarks (Branson); San Francisco of the South (Asheville), Lexington of Texas (Gonzales), Saratoga of the West (Manitou Springs), The Pittsburgh of the South (Birmingham), Newport in the Rockies (Colorado Springs), Little Austin (Denton), The Other Phoenix (Phoenix, Oregon), Hartford of the West (Lincoln, Nebraska), New England of the West (Minnesota). Деякі неофіційні найменування американських міст мають у своєму складі урбаноніми, зокрема назви відомих вулиць (Denver - Wall Street of the West, Jersey City - Wall Street West), районів (Kanab - Utah's Little Hollywood, Washington Hollywood for Ugly People) тощо.

Нам удалося знайти лише один приклад використання в неофіційній топонімії США назви географічного об’єкта Латинської Америки, а саме: Havana on the Hudson (Union City).

\footnotetext{
${ }^{1}$ n.d. - без дати
} 


\section{3. Міфоніми.}

Ця група онімів є нечисленною. До неї входять передусім біблійні топоніми (New York - The Modern Gomorrah, Sabina - The Eden of Ohio) та деякі інші вигадані географічні назви, як-от: Eldorado (міфічна країна золота та дорогоцінного каміння в Південній Америці, яку наполегливо й безуспішно шукали іспанські конкістадори XVI ст. (Wikipedia, n.d.)) i The Land of $\mathrm{Oz}$ (казкова країна, вигадана американським дитячим письменником Френком Баумом, автором «Дивовижного чарівника Країни Оз»), що стали основою неофіційних назв штату Каліфорнія (The Eldorado State) та канзаського міста Ліберал відповідно (The Land of $O z$ ).

Мотивація неофіційних назв міст і штатів США, що мають у своєму складі прецедентні топоніми, охоплює широке коло принципів, спільних для більшості найменувань цього типу (cf. Zosimova, 2016a; Zosimova, 2016b).

Походження досліджуваних одиниць може бути пов'язане з певними подіями в історії міст та штатів. Наприклад, Гонсалес (Gonzales) має неофіційну назву Lexington of Texas через те, що поблизу нього відбулася перша битва Техаської революції (1835-1836), тоді як саме в Лексінгтоні (Массачусетс) свого часу розпочалася Війна за незалежність США (1775-1783) (Wikipedia, n.d.). Неофіційне найменування Віксбурга - Gibraltar of America (the South, the Mississippi, the Confederacy). Як відомо, стародавні греки вважали Гібралтарську скелю в південній частині Піренейського півострова одним із Геркулесових стовпів і навіть не наважувалися пропливати повз неї. Потрапивши під контроль англійців у XVIII столітті, Гібралтар, як унікальний стратегічний пункт, що давав змогу контролювати вихід із Середземного моря й підходи до нього з Атлантики, став символом британського панування й непереможності на морях. У свою чергу американське місто Віксбург, розташоване на лівому березі Міссісіпі, також мало надзвичайно важливе стратегічне значення, тому битва за нього була однією з найбільш тривалих та кровопролитних під час Громадянської війни в США (1861-1865), що й зумовило виникнення перифразової номінації Gibraltar of America («Mississippi’s Rock», n.d.). Неофіційна назва Каліфорнії The Eldorado State нагадує про золоту лихоманку 1848-1855 pp., коли сотні тисяч людей прибули до цього регіону в пошуках багатства (Netstate, n.d.). Одна 3 неофіційних назв Чикаго - Beirut by the Lake - пов'язана з подіями XX століття, а саме з політичним протистоянням у місцевій владі 1980 -х років (т.зв. The Council Wars). Конфлікт мера Г. Вашингтона - першого афроамериканця на цій посаді - з вороже налаштованою білошкірою опозицією зумовив появу вигаданого журналістами прізвиська, заснованого на аналогії між тогочасним Чикаго та столицею Лівану Бейрутом, що багато років був осередком політичних, національних та релігійних суперечок (Wikipedia, n.d.).

Велика кількість неофіційних назв американських міст і штатів умотивована особливостями їхньої економіки. Так, топонім Birmingham (важливий промисловий центр Великої Британії) став основою неофіційного найменування Пітсбурга - одного з найбільших у світі виробників сталі: Birmingham of America. У свою чергу місто Бірмінгем у штаті Алабама називають The 
Pittsburgh of the South через те, що воно також є металургійним центром свого регіону. Назва іншого британського міста, знаного своєю текстильною промисловістю, уходить до складу прізвиська Лоуелла (штат Массачусетс), яке в XIX столітті мало значну кількість підприємств з обробки бавовни, що й зумовило появу перифразової номінації Manchester of America (Wikipedia, n.d.).

Назва фінансового центру Нью-Йорка Wall Street фігурує у назвах інших міст із відомими діловими центрами, де розташовані банки, фондові біржі, офіси великих компаній тощо, наприклад: Denver - Wall Street of the West, Jersey City - Wall Street West (Wikipedia, n.d.).

Національність мешканців міста також є вагомим чинником у формуванні неофіційних топонімів. Зокрема, понад 30\% населення Дейлі-Сіті (штат Каліфорнія) складають нащадки філіппінських іммігрантів, що й стало причиною виникнення прізвиська Little Manila, де Manila - столиця відповідної азійської країни (Wikipedia, n.d.). Одну з неофіційних назв штату Делавер - New Sweden - умотивовано національною належністю його перших постійних мешканців - вихідців із Свропи (Netstate, n.d.). Невеличке містечко Ліндсборг у Канзасі відоме як Little Sweden, оскільки його також заснували шведські переселенці (Wikipedia, n.d.). Подібні причини зумовили появу деяких інших неофіційних топонімів, зокрема: Little Norway (Poulsbo), Michigan's Little Bavaria (Frankenmuth), Scotland, USA (Alma), New England of the West (Minnesota), Havana on the Hudson (Union City) тощо. Частково наявність низки іммігрантських груп у Нью-Йорку також мотивує одне з його неофіційних найменувань - Hong Kong on the Hudson (Wikipedia, n.d.). Атланту називають Black Mecca через значну кількість афро-американців, які мають у цьому місті великі можливості для здобуття освіти, розвитку бізнесу, політичної кар'єри (Wikipedia, n.d.).

Особливості рельєфу та краса гірських ландшафтів багатьох штатів зумовили їхнє порівняння з такими європейськими країнами, як Швейцарія та Італія, наприклад: Switzerland of America (Colorado; West Virginia; Maine), Italy of America (Arizona). Численні річки та низовинний рельєф Луїзіани мотивують появу неофіційної номінації The Holland of America (Netstate, n.d.). Розмаїття форм рельєфу та ландшафту Меріленду - від гірської системи Аппалачі на заході до низовинних піщаних пляжів на сході штату $-€$ одним із головних чинників формування неофіційної назви America in Miniature (Wikipedia, n.d.).

Архітектура й історичні пам'ятки певного міста також часто інспірують появу неофіційних топонімів. Наприклад, місто Цинциннаті в XIX столітті було відоме як Paris of America завдяки таким амбітним на той час будівельним проектам, як місцевий готель (Cincinnatian Hotel), мюзик-хол, універмаг Шилліто та ін. (Wikipedia, n.d.). Унікальні архітектурні пам'ятки Коламбуса (Індіана), зокрема сучасні церкви в стилі модерн-арт (modern art), незвичайні за формою пошта й навіть в'язниця, цілком виправдовують появу прізвиська Athens of the Prairie ("Athens of the Prairie," 2014). Пропонуючи свій план масштабної відбудови та розвитку міста після Великої пожежі 1871 року, Деніел Бернгем бачив Чикаго як майбутній Париж, що зумовило відповідний 
вигляд майбутнього мегаполіса в розробленому архітектором проекті. Цей план, а згодом і саме місто, отримали назву Paris on the Prairie (Goldberger, 2009, March 9). Низка широких бульварів Канзас-Сіті та Детройта також дозволяє провести аналогію з Парижем, що відображено в номінаціях Paris of the Plains i Paris of the Midwest відповідно (Wikipedia, n.d.). Розгалужена мережа каналів у курортному містечку Форт-Лодердейл (Флорида) робить його схожим на Венецію, що й мотивує появу неофіційного найменування Venice of America (Wikipedia, n.d.).

Топонім Athens є основою неофіційних назв міст, що пишаються своїми здобутками у сфері культури, мистецтва та освіти, як-от: Athens of America (Philadelphia ("Athens of America," n.d.); Boston (Wikipedia, n.d.)), The Athens of the Mountains (Middlesboro - одне з небагатьох міст у гірському регіоні штату Кентуккі, що має великий оперний театр (Wikipedia, n.d.)), The Athens of Florida (DeLand - тут, зокрема, знаходиться найстаріший приватний коледж Флориди - Stetson University (Wikipedia, n.d.)), The German Athens of America (Milwaukee - це місто штату Вісконсин, понад 20\% населення якого становлять нащадки німецьких колоністів, має велику кількість музичних товариств, мистецьких і театральних груп тощо (“The Making of Milwaukee,” n.d.).

У місті Боулдер розташований найбільший університет штату Колорадо, що й зумовлює появу неофіційної номінації The Berkeley of the Rockies, де Berkeley - назва міста, де розташовано найстаріший кампус Каліфорнійського університету та низка інших відомих наукових інститутів і лаборатоpiй. До речі, цей вищий навчальний заклад ще з 1870 -х років називали Athens of the West. Згодом прізвисько стали використовувати на позначення самого Берклі (Wikipedia, n.d.). Така тенденція, за спостереженнями Девіда Боаза, загалом є характерною для міст, де розташовані коледжі, як-от: The Athens of the South (Nashville), Athens of the West (Lexington, Madison) (Boaz, 2011, February 28).

Неофіційні назви деяких рекреаційних центрів також мають в основі інші топоніми. Так, місто Колорадо-Спрінгз, засноване 1871 р. як елітний курорт, особливо приваблювало англійських туристів, що й зумовило появу номінації Little London (Wikipedia, n.d.). Наявність природних мінеральних джерел зближує Маніту-Спрінгз (Колорадо) із містом Саратога (НьюЙорк): Manitou Springs - Saratoga of the West. Відомий курорт Санта-Барбара називають Американською Рив'єрою (The American Riviera). Популярний серед туристів Бренсон (Miссурі) із його розвиненою індустрією розваг має неофіційне найменування Las Vegas of the Ozarks, де Ozarks - назва гір, у яких розташоване місто. Мідлсбро у штаті Кентуккі стало відомим як Little Las Vegas y 30 -х роках XX століття завдяки великій кількості гральних закладів і барів (Wikipedia, n.d.).

Репутація деяких міст США як центрів злочинності також зумовила виникнення неофіційних топонімів. Номінації на кшталт Little Chicago (Sioux City, Iowa; North Platte, Nebraska), Little Chicago of the South (Johnson City, Tennessee) з'явилися за доби «Сухого закону» 1920-х рр. через роль цих міст у підпільному виробництві, транспортуванні й продажі алкоголю (“Little 
Chicago," n.d.). Популярне нині найменування самого Чикаго - Chiraq $($ Chicago + Iraq) - натякає на сучасний розквіт злочинності в цьому місті, зокрема високий показник убивств (Wikipedia, n.d.).

Деякі неофіційні топоніми не пов'язані 3 конкретною сферою життя (економікою, культурою тощо), а вказують на важливу роль міста в регіоні, проводячи при цьому паралелі з певним загальновизнаним мегаполісом, як-от: New York of the South (New Orleans), The Chicago of the South (Decatur, Alabama).

Цікавим мотиваційним чинником є функція диференціації. Так, неофіційна назва міста Фінікса в Орегоні - The Other Phoenix - має на меті відрізнити цей населений пункт від більш відомого Фінікса - столиці штату Аризона.

\section{Висновки}

Неофіційні назви американських міст та штатів, що грунтуються на використанні прецедентних топонімів, насамперед пов'язані з історією й економікою певних населених пунктів чи регіонів, етнічною належністю перших поселенців чи нинішніх мешканців. Такі найменування часто характеризують особливості ландшафту, здобутки у сфері культури, мистецтва й освіти та вказують на інші прикметні риси міст і штатів США. У ролі прецедентних топонімів функціонують назви географічних об'єктів Старого й Нового Світу, що можуть бути як універсальними культурними символами (Athens, Paris, Baghdad, Mecca; New York, Las Vegas тощо), так і феноменами, актуальними для носіїв англійської мови, передусім американців (Birmingham, Manchester; Saratoga, Lexington тощо). Також досліджувані одиниці містять міфоніми - біблійні назви та специфічні номінації, відомі здебільшого представникам конкретної лінгвокультурної спільноти. У будь-якому разі розуміння мотивації неофіційних назв американських міст і штатів, що мають у своєму складі прецедентні топоніми, обов'язково потребує володіння фоновими знаннями, пов'язаними з історією, культурою, географією й економікою США.

Перспективи дослідження неофіційної топонімії вбачаємо в розгляді специфіки творення й мотивації інших груп прізвиськ американських міст і штатів, що поглибить наші уявлення про історію, традиції та своєрідність національного світобачення відповідної етнокультурної спільноти.

\section{ЛІТЕРАТУРА}

1. Канна В. Ю. Структура, функції та лексикографія конотативної топонімії: автореф. дис. на здобуття наук. ступеня канд. філол. наук: спец. 10.02 .15 «Загальне мовознавство». Донецьк, 2009. 17 с. 2. Леонович О. Предисловие. Краткий словарь английских прозвищ. Москва: Высшая школа, 2007. С. 3-13. 3. Селіванова О. О. Сучасна лінгвістика: термінологічна енциклопедія. Полтава: Довкілля-К, 2006. 716 с. 4. Титаренко О. Ю. Мовні засоби вираження гумору (на матеріалі творів англійської та американської літератури XIX-XX століть): автореф. дис. на здобуття наук. ступеня канд. філол. наук: спец. 10.02.04 «Германські мови». Київ, 1993. 16 с. 5. Томахин Г. Д. Реалии-американизмы. Пособие по страноведению. Москва: Высшая школа, 1988. 239 с. 6. Athens of America. The Encyclopedia of Greater Philadelphia. URL: http:// 
philadelphiaencyclopedia.org/events/the-athens-of-america (accessed 9 January, 2019). 7. Athens of the Prairie - Columbus, IN. URL: http://lowestravels.com/2014/07/30/athensof-the-prairie-columbus-in (accessed 9 January, 2019). 8. Boaz, D. Madison, Wisconsin: The Athens of the West. URL: http://www.cato.org/publications/commentary/madisonwisconsin-athens-west_(accessed 9 January, 2019). 9. Goldberger, P. Toddlin' Town: Daniel Burnham's great Chicago Plan turns one hundred. The New Yorker. URL: http://www. newyorker.com/magazine/ 2009/03/09/toddlin-town (accessed 9 January, 2019). 10. Little Chicago. URL: http://www.stateoffranklin.net/johnsons/_chicago/chicago.htm (accessed 9 January, 2019). 11. Mississippi’s Rock of Gibraltar. URL: http://www.americaslibrary.gov/ es/ms/ es_ms_gibrltar_1.html (accessed 9 January, 2019). 12. Netstate: Learn About the 50 States. URL: http://www.netstate.com/index.html (accessed 9 January, 2019). 13. The Making of Milwaukee: Ethnic Stories. URL: http://www.themakingofmilwaukee.com_/people/ stories.cfm (accessed 9 January, 2019). 14. Wikipedia: The Free Encyclopedia. URL: http:// en.wikipedia.org (accessed 9 January, 2019). 15. Zosimova, O. V. Main Types of Informal Place Names in the USA: A Motivational Perspective. Лінгвістичні дослідження: збірник наук. праць Харківського нац. пед. ун-ту імені Г.С. Сковороди. Харків, 2016. Вип. 41. C. 34-39. http://dx.doi.org/10.5281/zenodo.48530 16. Zosimova, O. V. Motivation of American Informal Place Names. Наукові записки Бердянського державного педагогічного університету. Філологічні науки: зб. наук. ст. Гол. ред. В. А. Зарва. Бердянськ, 2016. Вип. IX. С. 61-68.

\section{REFERENCES}

1. Kanna, V. Yu. (2009). Struktura, funktsii ta leksykohrafiia konotatyvnoi toponimii [Structure, functions and lexicography of connotative toponymy]. Extended abstract of candidate's thesis. Donetsk: DonNU [in Ukrainian]. 2. Leonovych, O. (2007). Predisloviie [Preface]. Kratkii slovar anhliiskikh prozvishch - A concise dictionary of English nicknames. (Pp. 3-13). Moscow: Vysshaia shkola [in Russian]. 3. Selivanova, O. O. (2006). Suchasna linhvistyka: terminolohichna entsyklopediia [Modern linguistics: encyclopedia of terminology]. Poltava: Dovkillia-K [in Ukrainian]. 4. Tytarenko, O. Yu. (1993). Movni zasoby vyrazhennia humoru (na materiali tvoriv anhliiskoi ta amerykanskoi literatury XIX-XX stolit) [Linguistic means of expressing humor (on the material of works of English and American Literature of the $19^{\text {th }}$ and $20^{\text {th }}$ centuries)]. Extended abstract of candidate's thesis. Kyiv: KSPIFL [in Ukrainian]. 5. Tomakhin, H. D. (1988). Realii-amerikanizmy. Posobiie po stranovedeniiu [American realia. A course book on country studies]. Moscow: Vysshaia shkola [in Russian]. 6. Athens of America. (n.d.). In The Encyclopedia of Greater Philadelphia. Retrieved from http://philadelphiaencyclopedia.org/events/the-athens-of-america 7. Athens of the Prairie - Columbus, IN. (2014, July 30). Retrieved from http://lowestravels.com/2014/07/30/athens-of-theprairie-columbus-in 8. Boaz, D. (2011, February 28). Madison, Wisconsin: The Athens of the West. Retrieved from http://www.cato.org/publications/commentary/madison-wisconsinathens-west 9. Goldberger, P. (2009, March 9). Toddlin' Town: Daniel Burnham's great Chicago Plan turns one hundred. The New Yorker. Retrieved from http://www.newyorker. com/ magazine/2009/03/09/toddlin-town 10. "Little Chicago" (n.d.). Retrieved from http://www.stateoffranklin.net/johnsons/chicago/chicago.htm 11. Mississippi's Rock of Gibraltar. (n.d.). In America's Library. Retrieved from http://www.americaslibrary.gov/es/ ms/es_ms_gibrltar_1.html 12. Netstate. Learn about the 50 States. (n.d.). Retrieved from http://www.netstate.com/index.html 13. The Making of Milwaukee: Ethnic Stories. (n.d.). Retrieved from http://www.themakingofmilwaukee.com/people/stories.cfm 14. Wikipedia: The Free Encyclopedia. (n.d.). Retrieved from http://en.wikipedia.org 15. Zosimova, O. V. (2016a). Main Types of Informal Place Names in the USA: A Motivational Perspective. Linhvistychni doslidzhennia - Linguistic studies: A selection of papers of H.S. Skovoroda Kharkiv 
National Pedagogical University. (Issue 41), (pp. 34-39). Kharkiv: KhNPU. http://dx.doi. org/10.5281/zenodo.48530 16. Zosimova, O. V. (2016b). Motivation of American Informal Place Names. V. A. Zarva (ed.), Naukovi zapysky Berdianskoho derzhavnoho pedahohichnoho universytetu. Filolohichni nauky - Academic Papers of Berdiansk State Pedagogical University. Philology Series: A selection of scholarly articles. (Issue IX), (pp. 61-68). Berdiansk: BSPU.

Зосімова Оксана Вімалї̈вна - кандидат філологічних наук, доцент, доцент кафедри практики англійського усного і писемного мовлення; Харківський національний педагогічний університет імені Г. С. Сковороди; вул. Валентинівська, 2, Харків, 61168, Україна.

Tel.: + 38 (0572) 68-43-25;

E-mail: oksanazosimova@ukr.net

http://orcid.org/0000-0002-5446-2222

Zosimova Oksana Vitaliivna - PhD in Philology, Associate Professor, Department of Practice of Oral and Written English, H.S. Skovoroda Kharkiv National Pedagogical University; Valentynivska Str., 2, Kharkiv, 61168, Ukraine.

Надійшла до редакції 04 лютого 2019 року 